\title{
Horizontal distribution of invertebrate larvae around the oceanic island of Gran Canaria: the effect of mesoscale variability
}

\author{
JOSÉ MARÍA LANDEIRA ${ }^{1}$, FERNANDO LOZANO-SOLDEVILLA ${ }^{1}$, \\ SANTIAGO HERNÁNDEZ-LEÓN ${ }^{2}$ and ERIC DESMOND BARTON ${ }^{3}$ \\ ${ }^{1}$ Departamento de Biología Animal, UDI Ciencias Marinas, Universidad de La Laguna, Spain. E-mail: jmlandei@ull.es \\ ${ }^{2}$ Laboratorio de Oceanografía Biológica, Facultad de Ciencias del Mar, Universidad de Las Palmas de Gran Canaria, \\ Spain. \\ ${ }^{3}$ Departamento de Oceanoloxía, Instituto de Investigaciones Marinas (CSIC), Vigo, Spain.
}

\begin{abstract}
SUMMARY: In October 1991, the horizontal distribution of invertebrate larvae was studied in the waters surrounding the island of Gran Canaria (Canary Islands). The cruise was typified by the presence of three recurrent mesoscale hydrographic structures: a cyclonic eddy southwest of the island, a warm lee region downstream of the island and the offshore boundary of an upwelling filament from the African coast reaching the southeast of the island. Decapod larvae were the most abundant group. In general, a rather high spatial variability was found. The horizontal distribution of the invertebrate larvae groups showed that the highest values of abundance occurred in an elongated zone around the island oriented in the overall direction of flow, leeward and windward of the island, while the lowest values occurred off the eastern and western flanks of the islands. On the other hand, Stomatopoda and Mollusca larvae showed a distribution associated with the boundary of the upwelling filament and decapod larvae of pelagic species were distributed around the eddy structure. Our results suggest specific retention mechanisms for the larvae of neritic invertebrate populations that are related to the particular physical oceanography around Gran Canaria.
\end{abstract}

Keywords: invertebrate larvae, decapod larvae, abundance, mesoscale variability, Canary Islands.

RESUMEN: Distribución horizonTal DE LAS LARVAS DE INVERTEBRAdOS ALREDEDOR DE LA ISLA OCEÁNICA DE GRAN CANARIA: EFECTO DE LA VARIABILIDAD DE MESOESCALA. - Se estudió la distribución horizontal de las larvas de invertebrados alrededor de la isla de Gran Canaria (Islas Canarias) en octubre de 1991. La campaña se caracterizó por la presencia de tres fenómenos oceanográficos de mesoescala recurrentes: un remolino ciclónico al suroeste de la isla, la estela cálida a sotavento de la misma y el borde de un filamento proveniente del afloramiento africano situado al sureste de Gran Canaria. Las larvas de crustáceos decápodos fueron las más abundantes. En general, las larvas de los diferentes taxa estudiados mostraron una gran variabilidad en cuanto a su distribución espacial. La distribución horizontal de las larvas de los diferentes grupos de invertebrados mostró que las densidades más altas se registraban alrededor de la isla en la banda cercana y orientada hacia el suroeste, en la dirección del flujo, mientras que los valores más bajos se encontraron en el norte y en los flancos este y oeste de la isla. Por otro lado, las larvas de estomatópodos y moluscos presentaron una distribución asociada al frente del filamento, mientras que las larvas de decápodos pelágicos se distribuyeron en torno al remolino ciclónico. Los resultados obtenidos sugieren la existencia de mecanismos de retención específicos para el mantenimiento de las poblaciones insulares, relacionados con los procesos físicos de mesoescala predominantes.

Palabras clave: larvas de invertebrados, larvas de decápodos, abundancia, variabilidad de mesoescala, Islas Canarias. 


\section{INTRODUCTION}

Gran Canaria is an almost circular island $(50 \mathrm{~km}$ in diameter) in the middle of the Canary Island Archipelago. This island rises steeply from ocean depths of $2000 \mathrm{~m}$ up to $1949 \mathrm{~m}$ above sea level, forming an obstacle to the southwestern flow of the Canary Current and the trade winds and therefore producing a significant downstream wake (Barton et al., 2000; Barton et al., 2001). Satellite imagery of sea-surface temperature shows a warm triangular lee region south of the island with repeated cold/warm-core eddies at its sides (Hernández-Guerra et al., 1993; Barton et al., 2000; Sangrà et al., 2007). Arístegui et al. (2005) reported that these persistent eddies spun off Gran Canaria throughout the year play an important role in the vertical pumping of nutrients. In addition, Arístegui et al. $(1994,1997)$ and Hernández-León et al. (2001) have shown that the eddy systems influence bacteria, phytoplankton and zooplankton distributions. Sometimes, filaments have been reported to act as a means of offshore transport of water masses from the northwest African upwelling to the vicinity of Gran Canaria by interacting with the eddies system (Hernández-Guerra et al., 1993; Barton et al., 2000; Barton et al., 2004). These upwelling filaments were reported as mechanisms for the transport of fish larvae from Africa to the Canary Islands responsible for reseeding the island population (Rodríguez et al., 1999, 2004; Bécognée et al., 2006).

Most invertebrate species produce planktonic larvae, which can remain in the plankton from a few minutes to several months (Shanks, 1995). This phase of development can constitute the most important dispersal period in their life cycle. The degree of dispersal of invertebrate larvae and recruitment mainly depends on pelagic larval duration and the local oceanographic features. It is frequently assumed in regard to larval dispersal in marine populations that (1) dispersal is primarily passive, (2) dispersal distances are typically long, (3) recruitment into a population comes from outside sources, and therefore, (4) populations are primarily "open" (Cowen et al., 2002; Shanks and Eckert, 2005). Therefore, marine populations around oceanic islands with no clear upstream source of recruitment and situated in a unidirectional current such as the Canary Islands could be washed away if no mechanisms to retain and maintain the larvae near their natal populations were available. Nevertheless, mounting evidence suggest that some benthic marine organisms may be less demographically "open" than previously thought (Sponaugle et al., 2002). Islands normally have coastal retention zones that allow the maintenance of the larvae near their natal sites, as a result of interaction of the main current flow with the topographic relief (capes, banks, headlands and embayments). This interaction produces a complex flow field characterised by eddies, fronts, convergence, upwelling/ downwelling and jets that can have strong effects on the nearshore distribution of larvae as well as the location and intensity of larval recruitment (Sponaugle et al., 2002; Largier, 2004). Previous studies carried out in Gran Canaria waters showed that the north and the south of the island constituted stagnation points or regions of weak flow that had the highest densities of eggs and fish larvae (Rodríguez et al., 2001; Bécognée et al., 2006). In addition, Rodríguez et al. (2001) observed in October 1991 that the cyclonic eddy located offshore on the southwestern flank of Gran Canaria also acted as a strong retention zone.

In this paper, we report on the horizontal distribution of invertebrate larvae (especially decapod larvae) around Gran Canaria. In addition, we describe the coupling between the physical environment present around this island and larvae abundance.

\section{MATERIALS AND METHODS}

The data studied in this paper were obtained during the second part of the CANARIAS 9110 cruise on board R.V. Ignat Pavlyuchenkov, from 25 October to 4 November 1991. The cruise took place during the period of greatest stratification of the water column and weak wind conditions in the Canaries region and consisted of a grid of 40 stations around Gran Canaria Island (Fig. 1). The description of the oceanography is based on previous studies carried out on the same cruise (Arístegui et al., 1997; Barton et al., 1998; Rodríguez et al., 2001). At each station, conductivity-temperature-depth casts were made down to $500 \mathrm{~m}$ by Neil Brown Mark III CTD (Vélez-Muñoz, 1992; Arístegui et al., 1997). Planktonic invertebrate larvae were collected in 22 oblique hauls from $200 \mathrm{~m}$ depth up (or about $5 \mathrm{~m}$ above the bottom at the shallower Stations 33, 38 and 44) to the surface. These samples were taken with a Bongo 40 net fitted with $250 \mu \mathrm{m}$ mesh and equipped with two General Oceanics flowmeters. One of the paired samples was preserved in 5\% buffered formaldehyde. In the laboratory, all invertebrate larvae were 


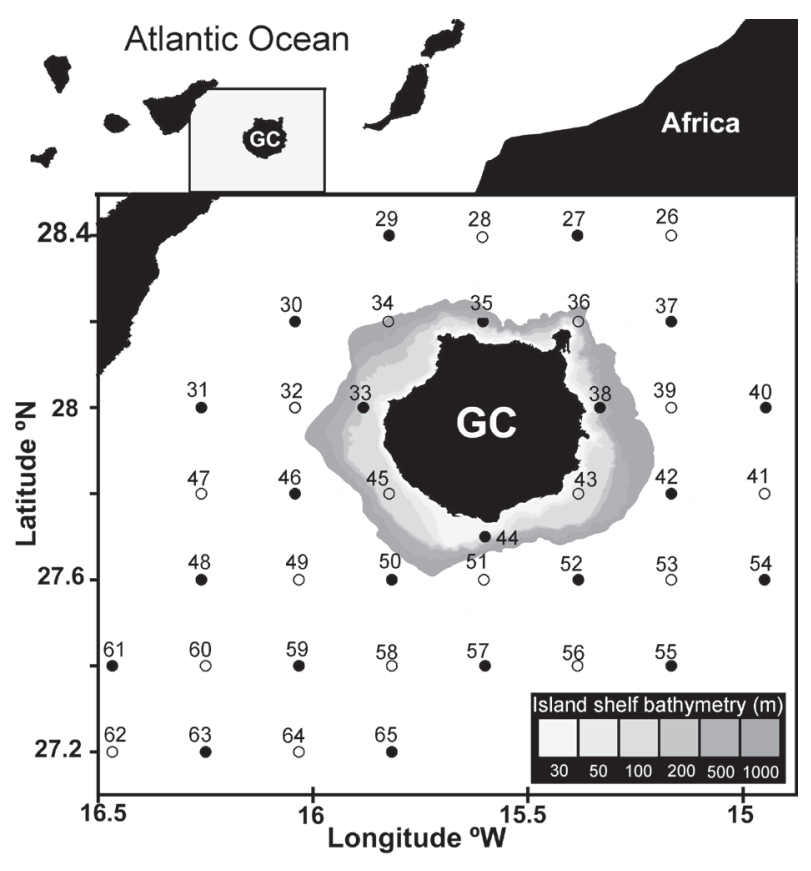

FIG. 1. - Location of the grid of CTD stations around Gran Canaria (GC). The filled symbols correspond to stations sampled for planktonic invertebrate larvae.

sorted and counted. The number of larvae of each invertebrate group was standardised per $100 \mathrm{~m}^{3}$. The decapod larvae group were identified to the lowest possible taxon using primarily the identification keys of dos Santos and Lindley (2001) and dos Santos and González-Gordillo (2004). The decapod taxa set was classified into different functional groups according to Shanks and Eckert (2005). Firstly, taxa were divided into two main groups depending on whether adults are distributed along the pelagic or benthic range. In addition, three subgroups were defined in the benthic group: nearshore habitats (from the intertidal zone to depths $\leq 50 \mathrm{~m}$ ), shelf/slope habitats (from $50 \mathrm{~m}$ depth, including the island shelf) and finally, a group that includes a number of species with depth ranges that extend into the nearshore zone but are also found commonly at greater depth over the island shelf. This last subdivision was made because of the large depth-dependent differences in the oceanography of the nearshore and shelf region of the island. Therefore, four functional groups were defined: pelagic species $(\mathrm{P})$, benthic nearshore species $(\mathrm{BN})$, benthic shelf/slope species (BS) and benthic species with a wide depth range distribution (BH). Data on the depth range distributions of adult decapod crustaceans are mainly from ZariquieyÁlvarez (1968), González-Pérez (1995) and Udekem D’Acoz (1999).

\section{RESULTS}

\section{Hydrology}

Hydrographic conditions during the cruise were described in detail by Arístegui et al. (1997), Barton et al. (1998) and Rodríguez et al. (2001). Briefly, the sampling period was characterised by the presence of higher surface temperatures, $21.5-23^{\circ} \mathrm{C}$ (annual values of $18-24^{\circ} \mathrm{C}$ ), strong stratification of the water column and southeastern winds with low intensity $\left(<15 \mathrm{~km} \cdot \mathrm{h}^{-1}\right)$ typical of this period of the year. The three recurrent mesoscale hydrological structures (Fig. 2) found were: (1) a cyclonic eddy, southwest of the island, with a cold core located at Station 59, (2) a warm lee region downstream of the island and (3) a relatively cold-water filament reaching the southeast of the island from the upwelling area off the African coast. The position of these structures was evidenced by the depth distribution of the $18^{\circ} \mathrm{C}$ isotherm, surface temperature and geostrophic flow maps (Fig. 2). However, the persistent cloud cover precluded any use of AVHRR sea-surface temperature during the cruise (Barton et al., 1998). According to Rodríguez et al. (2001), the strongest flows (about $0.3 \mathrm{~m} \mathrm{~s}^{-1}$ ) were observed along the boundary of the upwelling filament and cyclonic eddy and along the island flanks, mainly the western flank, where the canalisation of the general flow, due to the proximity of Tenerife Island, produces the acceleration of the current (Fig. 2). In addition, the north-northeast (upstream) and the lee (downstream) of Gran Canaria Island were reported as regions of weak or null flow by Rodríguez et al. (2001).

\section{Invertebrate larvae}

In total, 739 invertebrate larvae were counted and sorted (425 Decapoda, 36 Cirripedia, 4 Stomatopoda, 42 Echinodermata, 184 Polychaeta, 46 Mollusca and 2 Phoronida). The most abundant larval group, decapod larvae, were identified and divided into 51 different taxa (with a distribution of $4.9 \% \mathrm{P}, 6.7 \% \mathrm{BS}$, $46.65 \% \mathrm{BN}$ and $41 \% \mathrm{BH}$ ), showing average values of abundance of $19.4 \pm 48.2$ larvae $/ 100 \mathrm{~m}^{3}$ (Table 1). The second most important larval group was Polychaeta $\left(6.1 \pm 9\right.$ larvae $\left./ 100 \mathrm{~m}^{3}\right)$, followed by Mollusca $\left(1.6 \pm 2\right.$ larvae $\left./ 100 \mathrm{~m}^{3}\right)$ and Echinodermata $(1.5 \pm$ 2.3 larvae $/ 100 \mathrm{~m}^{3}$ ), mainly represented by high larval densities of Gastropoda and Echinoidea. In general, strong spatial variability was found. The horizontal 

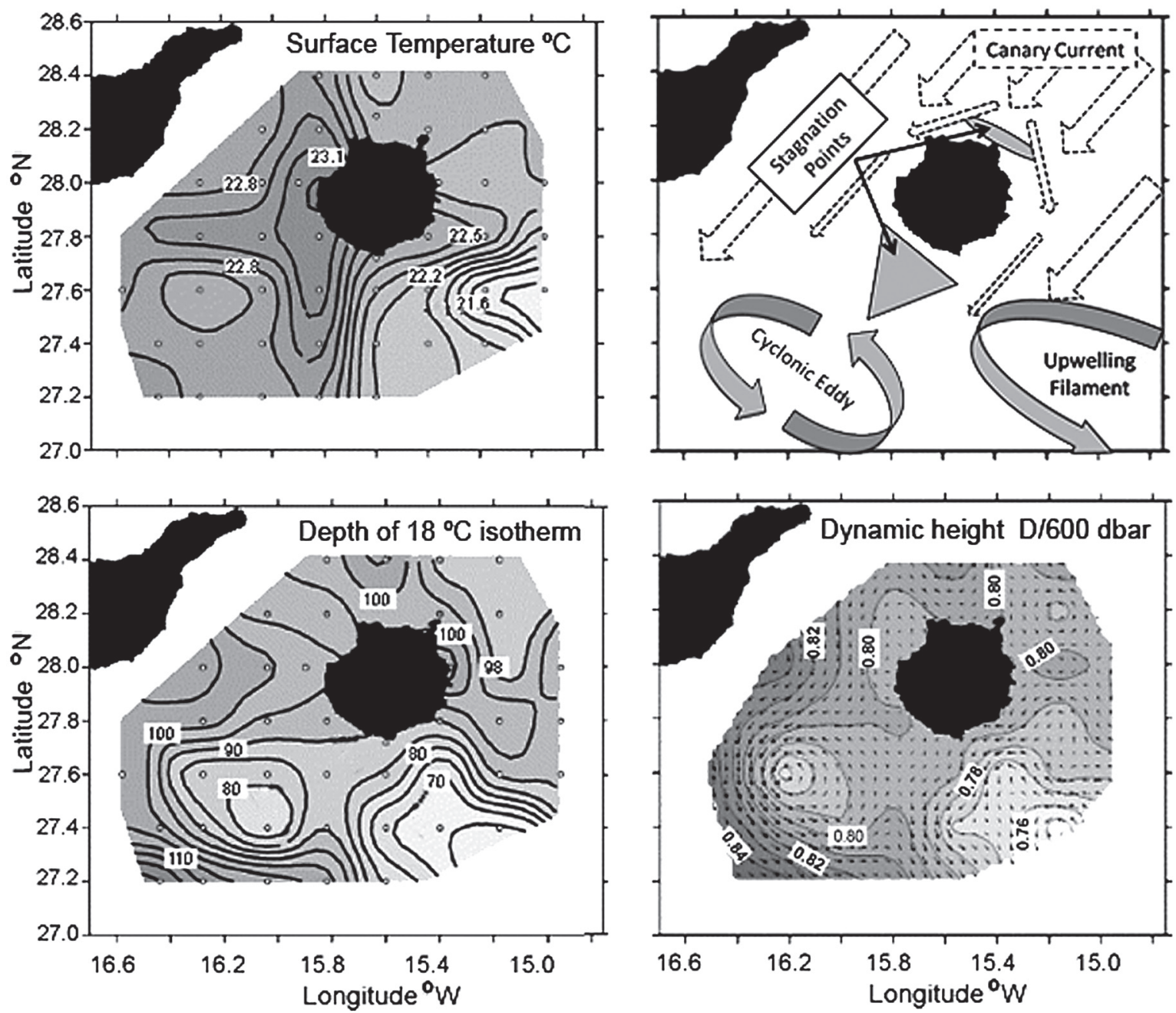

FIG. 2. - Topography of the surface temperature ${ }^{\circ} \mathrm{C}(\mathrm{A})$; idealised summary of the typical near-surface currents around the island (B); Horizontal distribution of dynamic topography of sea surface relative to $\mathrm{D} / 600$ dbar pressure (C) and the $18^{\circ} \mathrm{C}$ isotherm depth $\mathrm{m}$ (D) (redrawn from Rodríguez et al., 2001).

distribution of the different invertebrate larval groups was skewed, with the highest values downstream near the island and the lowest on its upstream side. Overall, the distributions were aligned with the direction of general flow, i.e. NE-SW (Fig. 3). All invertebrate larvae displayed the highest values at Station 44 located nearshore in the lee of the island, while Station 40 located on the eastern flank displayed very low densities, with only two Polychaeta larvae collected there. In addition, Polychaeta, Cirripedia, Echinodermata and Phoronida larvae showed local maxima in the position of the cold core eddy, southwest of Gran Canaria, while Stomatopoda and Mollusca larvae showed high abundances associated with the boundary of the upwelling filament (Fig. 3).

Regarding decapod larvae abundance (Fig. 4), the pelagic species larvae $(\mathrm{P})$ showed the lowest densities $\left(0.9 \pm 1.4 \mathrm{sd}\right.$ larvae $\left./ 100 \mathrm{~m}^{3}\right)$, Gennadas spp. and
Sergestes pectinatus Sund, 1920, being the dominant species, while the larvae of neritic species (BN) showed the highest values $(8.6 \pm 18.8$ larvae/100 $\mathrm{m}^{3}$ ), mainly due to the abundance of Alpheus glaber (Olivi, 1792), Latreutes fucorum (J.C. Fabricius, 1775) and Calcinus tubularis (Linnaeus, 1767) (Table 1). Other species belonging to the groups (BS) and (BH), such as Plesionika spp., Pagurus spp. and Bathynectes spp., achieved remarkably high abundances (Table 1). Additionally we report the presence of 2 larvae of Crangon allmani Kinahan, 1857 in the fourth zoeal stage of development at Station 35 and 2 larvae of Parapenaeus longirostris (Lucas, 1846) in Protozoea III stage at Station 54, which constitute new records for the Canary Islands area Udekem D'Acoz (1999).

The decapod larvae showed a similar distribution to other invertebrate larvae (Fig. 3). However, 

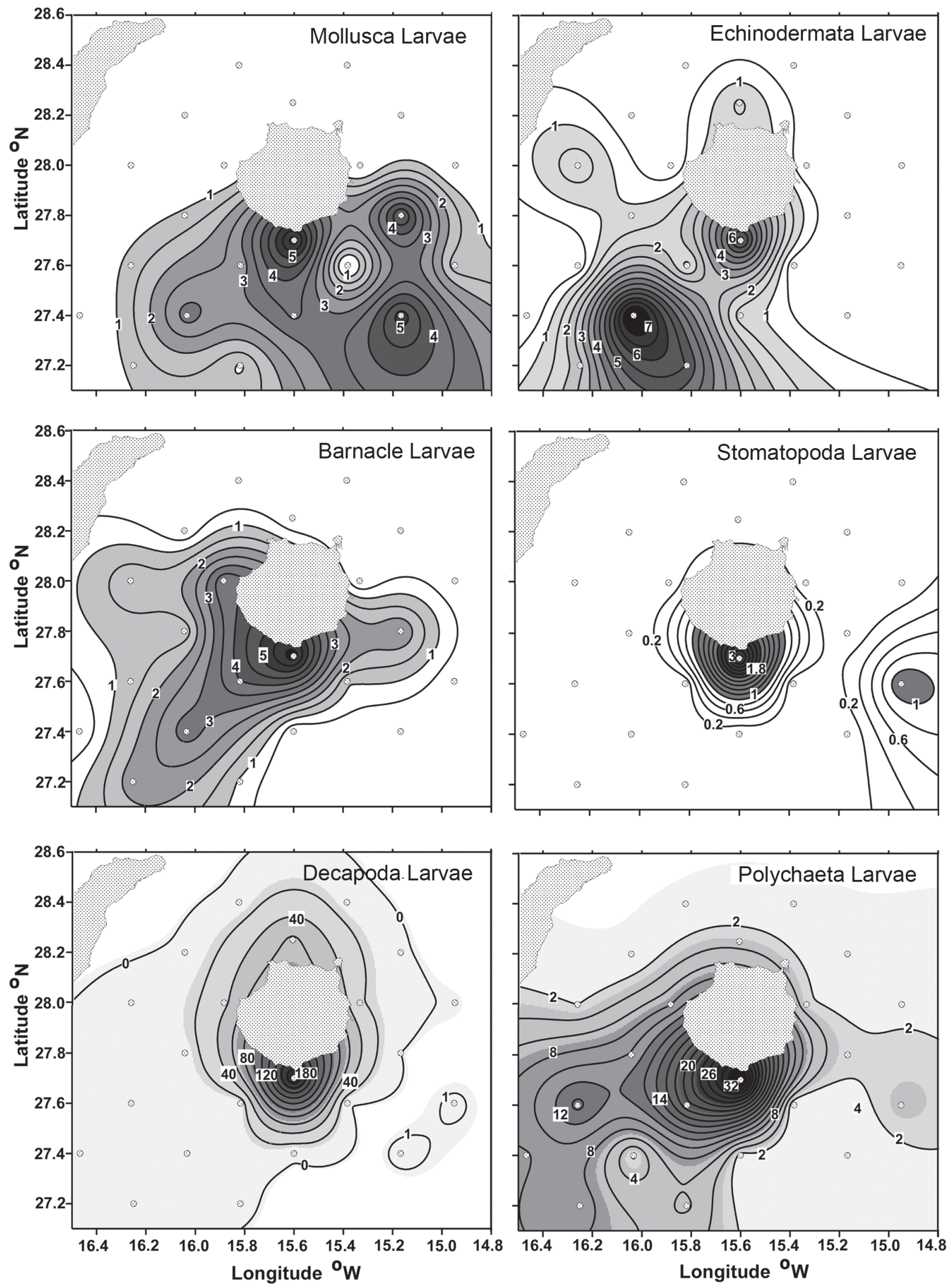

FIG. 3. - Horizontal distributions of larval abundance (larvae/100 $\mathrm{m}^{3}$ ) for the invertebrate groups. Circles refer to the sampled stations 

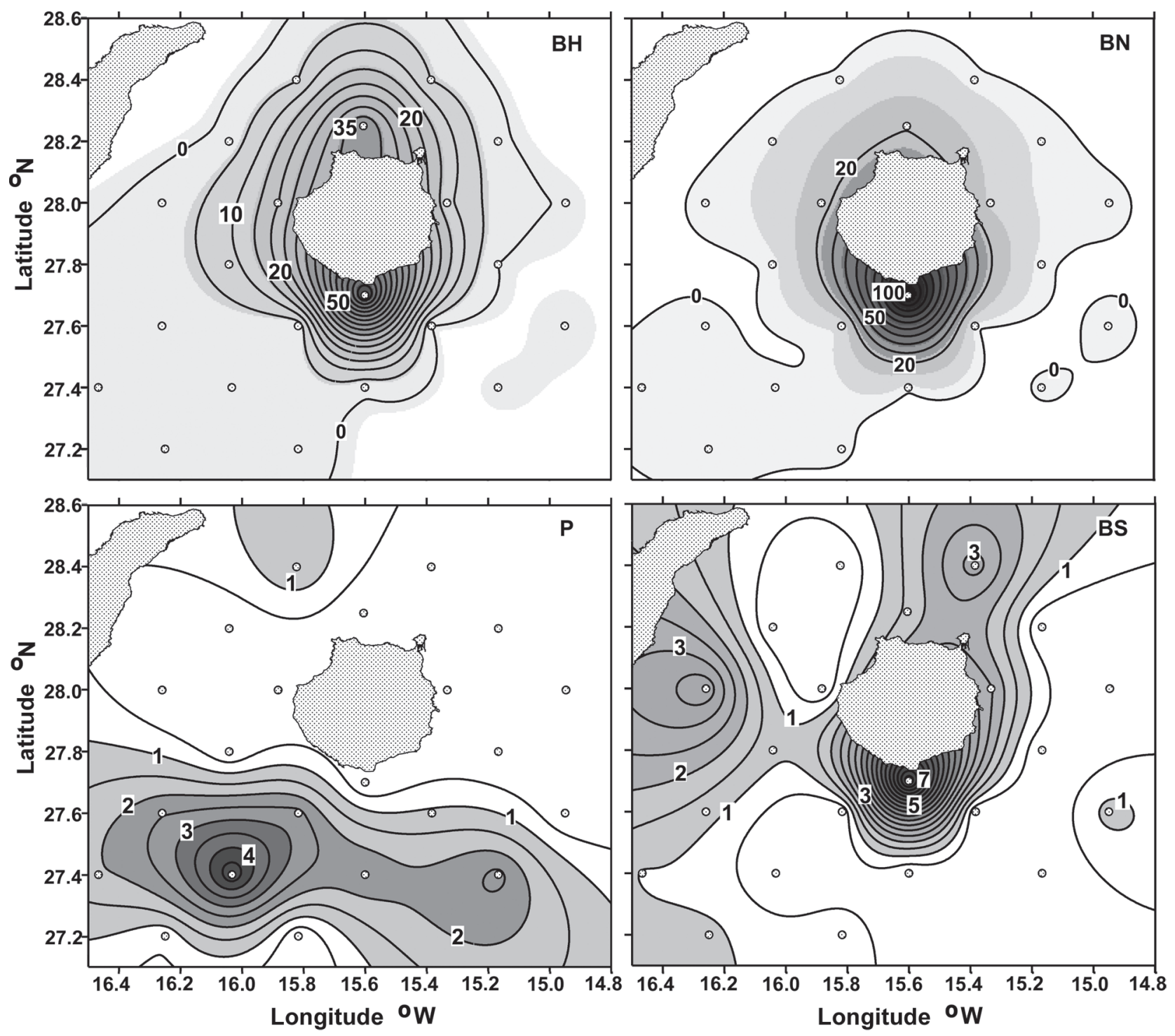

FIG. 4. - Horizontal distribution of decapod larvae abundance (larvae $/ 100 \mathrm{~m}^{3}$ ). BH refers to decapod larvae of benthic species with wide depth range distribution, $\mathrm{BN}$ to benthic nearshore species, BS to benthic shelf/slope species and $\mathrm{P}$ to larvae of pelagic species. Circles refer to the sampled stations.

when the spatial transport of the different decapod larvae functional groups was represented, the larvae of benthic species (BN, BH, BS) showed an opposite tendency to that of the pelagic (P) ones (Fig. 4). The larvae of benthic species decreased in abundance in an offshore direction while those of pelagic species increased. High abundances of larvae of pelagic species were displayed in the core of the cyclonic eddy (Station 59) and at the frontal zone of the upwelling filament. The distribution of Gennadas spp. (Fig. 5J) is a clear example of this pelagic pattern. In addition, other pelagic species such as Sergestes cornutus, $S$. atlanticus and $P$. longirostris were also present southward offshore. In contrast, the larvae of benthic species mainly showed maximum values over the island shelf, at Station 44 off the south coast (Fig. 4). However, we found different distribution pattern in the benthic species. Firstly, we found some species widely distributed: Calcinus tubularis (Fig. 5A, B), N. melanodactyla (Fig. 5D), Sergestes sargassi and Plesionika spp. (Fig. 5G). Other species were strongly associated with the area close to the island: Latreutes fucorum (Fig. 5C), Galathea intermedia (Fig. 5E), Pagurus spp. (Fig. 5F), Processa spp., Munida spp., and Alpheus macrocheles. Finally, some species were distributed exclusively offshore, related to the perturbed zone, where the eddy and filament occur: Pecnon gibbesi (Fig. 5I), Scyllarus 


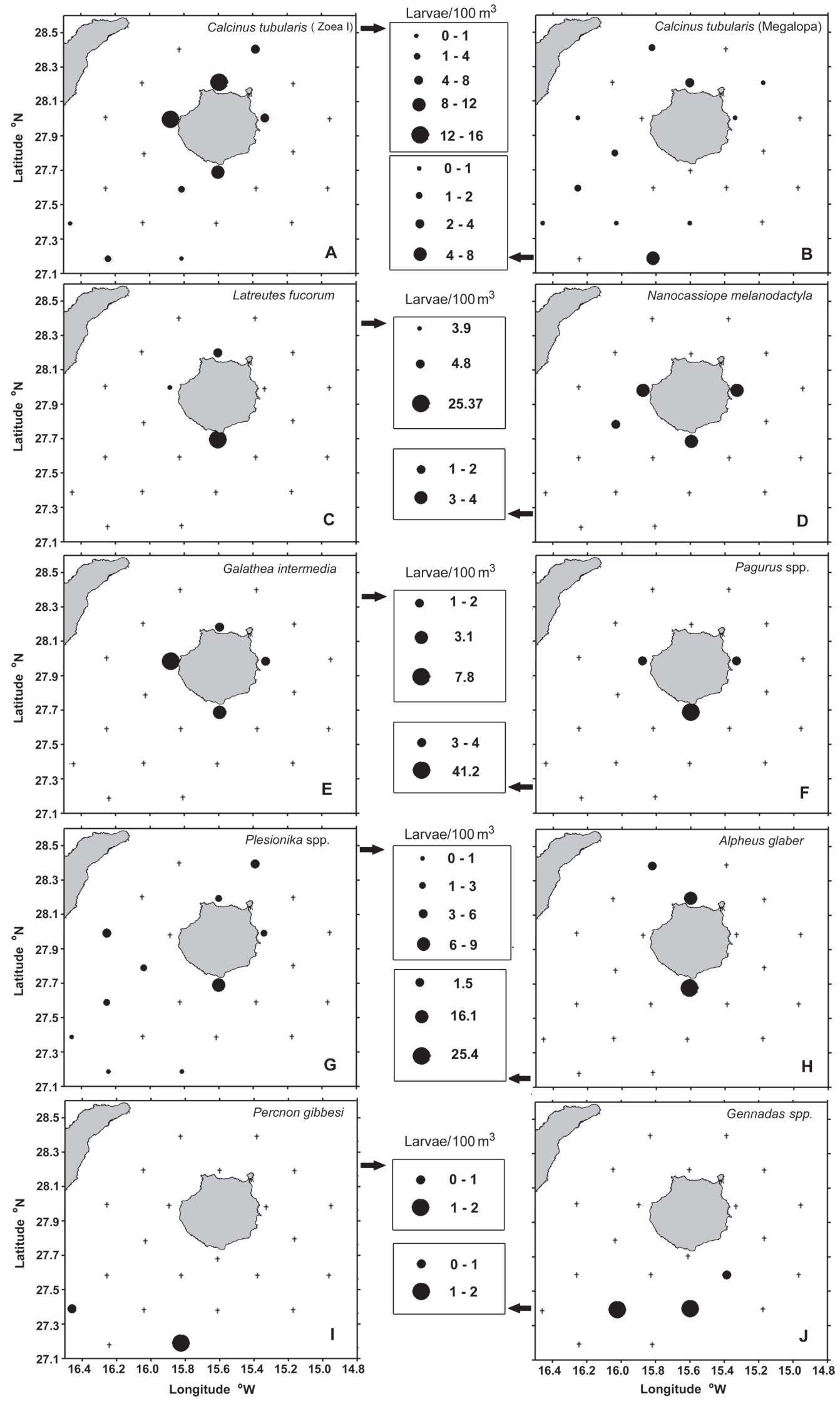

FIG. 5. - Horizontal distribution of the most representative decapod larvae (larvae/100 $\mathrm{m}^{3}$ ). Crosses refer to the sampled stations. 
TABLE 1. - List of decapod larvae caught. Horizontal distribution displayed: A (nearshore stations around Gran Canaria and in the warm lee region), $\mathrm{B}$ (eddy region) $\mathrm{C}$ (upwelling filament region) and $\mathrm{D}$ (undisturbed zone). Adult habitat (BH, benthic species with wide depth range distribution; BN, benthic nearshore species; BS, to benthic shelf/slope species; P to larvae of pelagic species). Mean values of abundance (larvae/100 $\mathrm{m}^{3}$ ) and their percentage of total. (*) First records for the Canary Islands.

\begin{tabular}{|c|c|c|c|c|c|c|c|}
\hline Taxa & A & $\mathrm{B}$ & $\mathrm{C}$ & $\mathrm{D}$ & Adult habitat & Mean & $\%$ \\
\hline Decapoda & & & & & & 19.45 & \\
\hline Aristeus spp. & $\mathrm{X}$ & & & & $\mathrm{BS}$ & 0.06 & 0.30 \\
\hline Gennadas spp. & & $\mathrm{X}$ & $\mathrm{X}$ & & $\mathrm{P}$ & 0.18 & 0.92 \\
\hline Parapenaeus longirostris* & & & $\mathrm{X}$ & & BS & 0.05 & 0.28 \\
\hline Sergestes atlanticus & & $\mathrm{X}$ & & & $\mathrm{P}$ & 0.06 & 0.29 \\
\hline Sergestes cornutus & & & $\mathrm{X}$ & & $\mathrm{P}$ & 0.06 & 0.31 \\
\hline Sergestes henseni & $X$ & & $\mathrm{X}$ & & $\mathrm{P}$ & 0.11 & 0.59 \\
\hline Sergestes pectinatus & & $\mathrm{X}$ & & $\mathrm{X}$ & $\mathrm{P}$ & 0.19 & 0.96 \\
\hline Sergestes sargassi & $\mathrm{X}$ & $\mathrm{X}$ & $\mathrm{X}$ & & $\mathrm{P}$ & 0.15 & 0.76 \\
\hline Sergestes vigilax & & $\mathrm{X}$ & & & $\mathrm{P}$ & 0.06 & 0.29 \\
\hline Acantephyra spp. & $\mathrm{X}$ & & & & $\mathrm{P}$ & 0.12 & 0.61 \\
\hline Palaemon elegans & $X$ & & & & $\mathrm{BN}$ & 0.07 & 0.38 \\
\hline Latreutes fucorum & $\mathrm{X}$ & & & & $\mathrm{BN}$ & 1.55 & 7.98 \\
\hline Pontoninae spp. & $\mathrm{X}$ & & & & $\mathrm{BN}$ & 0.15 & 0.75 \\
\hline Alpheus glaber & $\mathrm{X}$ & & & $X$ & $\mathrm{BN}$ & 1.95 & 10.04 \\
\hline Alpheus macrocheles & $\mathrm{X}$ & & & & $\mathrm{BN}$ & 0.34 & 1.73 \\
\hline Athanas nitescens & $\mathrm{X}$ & & & & $\mathrm{BN}$ & 0.51 & 2.61 \\
\hline Alpheidae spp. & & $\mathrm{X}$ & & $\mathrm{X}$ & $\mathrm{BN}$ & 0.37 & 1.93 \\
\hline Processa edulis crasipes & $\mathrm{X}$ & & & & $\mathrm{BH}$ & 0.18 & 0.92 \\
\hline Processa modica modica & $\mathrm{X}$ & & & & $\mathrm{BH}$ & 0.14 & 0.74 \\
\hline Processa nouveli holthuisi & $\mathrm{X}$ & & & & $\mathrm{BH}$ & 0.13 & 0.69 \\
\hline Processa nouveli nouveli & $\mathrm{X}$ & & & & $\mathrm{BH}$ & 0.72 & 3.71 \\
\hline Processa EM6 & $X$ & & & & $\mathrm{BH}$ & 0.36 & 1.84 \\
\hline Plesionika spp. & $X$ & $\mathrm{X}$ & $\mathrm{X}$ & $\mathrm{X}$ & BS & 0.97 & 4.96 \\
\hline Pandalidae spp. & $\mathrm{X}$ & $\mathrm{X}$ & & & BS & 0.17 & 0.88 \\
\hline Crangon allmani* & $\mathrm{X}$ & & & & $\mathrm{BH}$ & 0.07 & 0.38 \\
\hline Philocheras bispinosus neglectus & $\mathrm{X}$ & & & & $\mathrm{BN}$ & 0.14 & 0.74 \\
\hline Philocheras sculptus & $\mathrm{X}$ & & & & $\mathrm{BH}$ & 0.07 & 0.38 \\
\hline Scyllarus spp. & & & $\mathrm{X}$ & & $\mathrm{BN}$ & 0.04 & 0.21 \\
\hline Calcinus tubularis & $\mathrm{X}$ & $\mathrm{X}$ & $\mathrm{X}$ & $\mathrm{X}$ & $\mathrm{BN}$ & 0.86 & 4.44 \\
\hline Dardanus arrosor & $\mathrm{X}$ & & & & $\mathrm{BH}$ & 0.14 & 0.74 \\
\hline Pagurus alatus & $\mathrm{X}$ & & & & $\mathrm{BH}$ & 0.36 & 1.87 \\
\hline Pagurus spp. & $X$ & & & & $\mathrm{BH}$ & 2.23 & 11.45 \\
\hline Galathea intermedia & $\mathrm{X}$ & & & & $\mathrm{BN}$ & 0.63 & 3.25 \\
\hline Munida spp. & $\mathrm{X}$ & & & & $\mathrm{BH}$ & 0.12 & 0.60 \\
\hline Ebalia tumefacta & $\mathrm{X}$ & & & & $\mathrm{BH}$ & 0.44 & 2.25 \\
\hline Ilia nucleus & $\mathrm{X}$ & & & $\mathrm{X}$ & $\mathrm{BN}$ & 0.15 & 0.76 \\
\hline Achaeus cranchii & $\mathrm{X}$ & & & & $\mathrm{BN}$ & 0.06 & 0.30 \\
\hline Pisinae spp. & $\mathrm{X}$ & & & & $\mathrm{BN}$ & 0.65 & 3.34 \\
\hline Majidae S11 & $\mathrm{X}$ & & & & $\mathrm{BH}$ & 0.93 & 4.76 \\
\hline Parthenope spp. & $\mathrm{X}$ & & & & $\mathrm{BH}$ & 0.07 & 0.38 \\
\hline Atelecyclus spp. & $\mathrm{X}$ & & & $\mathrm{X}$ & $\mathrm{BH}$ & 0.12 & 0.62 \\
\hline Pirimela denticulata & $\mathrm{X}$ & & & $\mathrm{X}$ & $\mathrm{BN}$ & 0.63 & 3.23 \\
\hline Bathynectes spp. & $\mathrm{X}$ & & & $\mathrm{X}$ & $\mathrm{BH}$ & 1.29 & 6.63 \\
\hline Calappa granulata & $\mathrm{X}$ & & & & $\mathrm{BH}$ & 0.35 & 1.78 \\
\hline Nanocassiope melanodactyla & $\mathrm{X}$ & & & $\mathrm{X}$ & $\mathrm{BN}$ & 0.55 & 2.82 \\
\hline Xantho pilipes & $\mathrm{X}$ & $\mathrm{X}$ & & & $\mathrm{BN}$ & 0.23 & 1.20 \\
\hline Pachygrapsus marmoratus & & $\mathrm{X}$ & & & $\mathrm{BN}$ & 0.08 & 0.42 \\
\hline Percnon gibbesi & & $\mathrm{X}$ & $\mathrm{X}$ & & $\mathrm{BN}$ & 0.13 & 0.65 \\
\hline Plagusia depressa & & & & $\mathrm{X}$ & $\mathrm{BN}$ & 0.13 & 0.66 \\
\hline Grapsinae spp. & & $\mathrm{X}$ & & & $\mathrm{BN}$ & 0.07 & 0.38 \\
\hline Unidentified Brachyura & & & & & & 0.26 & 1.31 \\
\hline
\end{tabular}

spp., and Grapsinae spp, but always achieving low densities (Table 1).

To evaluate the capability of the decapod larvae of neritic species to stay close to the island, the horizontal distributions of the zoea I stage of development (Fig. 6A) and the megalopa stage (Fig. 6B) were plotted separately. The spatial distribution of zoea I showed a clear association with the shallow stations around the island, near the adult populations.
In addition, patches of abundance were observed to the northeast of the island and at the boundary of the cyclonic structure (Fig. 6A). On the other hand, the horizontal distribution of the megalopa larval stages showed a maximum abundance at the coastal Station 35 off the north of Gran Canaria. The spatial distribution also appeared elongated downstream of the island through the western flank (Fig. 6B). The same distribution pattern was displayed by the zoea I and 

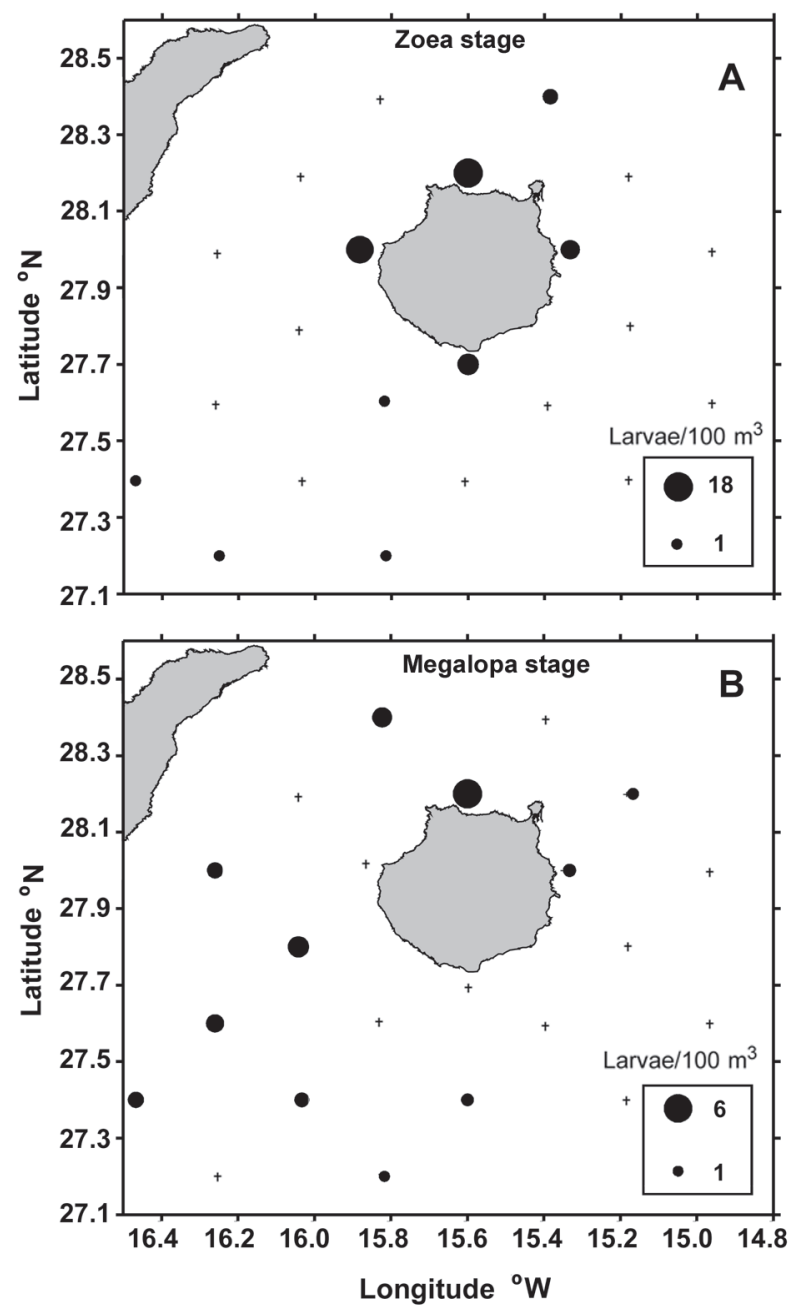

FIG. 6. - Horizontal distribution of neritic decapod larvae abundance (larvae $/ 100 \mathrm{~m}^{3}$ ) in different larval stages of development. (A) larvae in first zoeal stage; (B) larvae in megalopa stage of development. Crosses refer to the sampled stations.

megalopa of Calcinus tubularis, one of the neritic species (Fig. 5A, B).

\section{DISCUSSION}

The waters around Gran Canaria are a natural marine laboratory where oceanwide mesoscale processes such as wind shearing, fronts, eddies and upwelling filaments coexist in a small region (Arístegui and Montero, 2005). These oceanographic phenomena strongly influence the horizontal distribution of invertebrate larvae. Taking into account the larval distribution, our results suggest the separation of three main regions around Gran Canaria. The first region (A) is a highly retentive area, where we found the highest densities of most taxa studied. This region

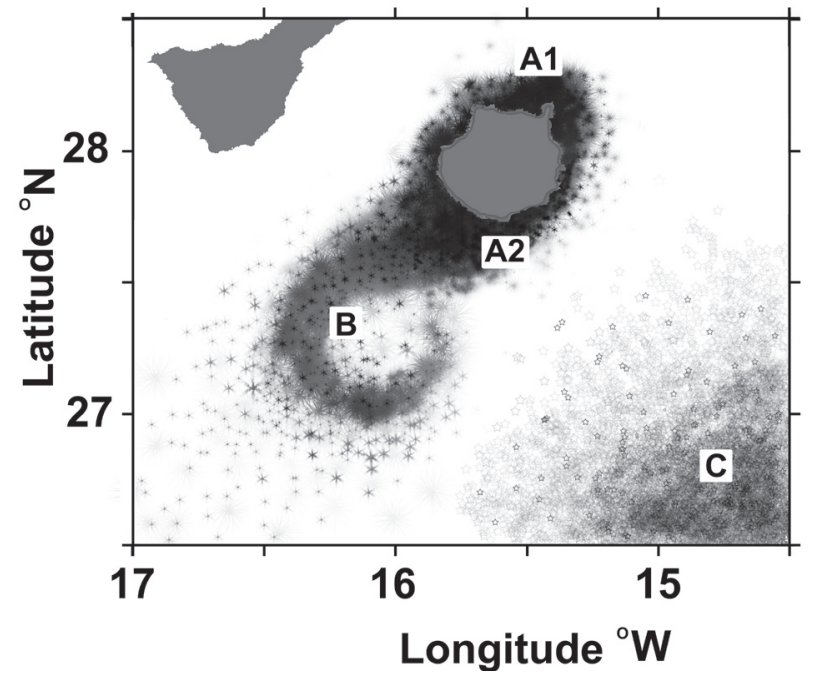

FIG. 7. - Proposed mechanisms for the physical-biological coupling in the field around Gran Canaria. A, High larval retention zone associated with the island shelf (A1, stagnation area upstream of the island; A2, stagnation area in the warm lee downstream); B, moderate retention zone related to the cyclonic eddy; $\mathrm{C}$, zone of African larvae transported by the upwelling filament effect.

is located on the island shelf, including A1 (stagnation point upstream) and A2 (lee of the island). The second region (B) is influenced by the presence of significant oceanographic activity with remarkable larval abundances. This area is a moderately retentive zone related to the cyclone eddy. Finally, the third region $(\mathrm{C})$ is associated with the upwelling filament that contains a potential larval input coming from the African coast (Fig. 7).

The lee region downstream of the island (mainly Station 44) showed the highest densities of invertebrate larvae. This accumulation in the wake of the island is an important result of the island mass effect, which was previously reported by HernándezLeón (1991) and Rodríguez et al. (2001), who found the highest values of zooplankton biomass, fish eggs and neritic fish larvae abundance in this lee region of Gran Canaria. The higher larval densities of decapod neritic species found at the nearshore stations also suggest larval retention in coastal waters around the island. The first stage of development of decapod coastal species was homogeneously distributed over the island shelf while the greatest concentration of megalopa larvae (advanced stage) was found off the north of the island, at Station 35. Rodríguez et al. (2001) also found higher concentrations of neritic fish larvae there, reporting this region as an area of weak flow around the stagnation point upstream of the island where the oncoming Canary Current diverges. The Lagrangian simulations of particles trajectories, presented by these authors, showed a 
greater number of both passive and swimming particles within the lee. Therefore, the retention zones located in the lee of Gran Canaria (downstream) and at the stagnation point (upstream), probably aided by the presence of internal waves on the shelf of Gran Canaria (Sangrà et al., 2001) and by the larval behaviour (horizontal swimming and vertical movements), could be responsible for the maintenance of the neritic populations of the island. Several authors have studied the nearshore currents and their effect on retention of larvae near their natal populations in upwelling systems. Shanks et al. (2003) correlated retention of larval meroplankton with the presence of topographically generated fronts, while Pineda $e t$ al. (1994) reported a shoreward transport of planktonic larvae by internal tidal bores.

The cyclonic eddy observed downstream of the island also influenced the horizontal distribution of invertebrate larvae. The neritic larvae could become trapped in the cyclonic eddy as it separates from the shore with the southwestward drift of the Canary Current, thus moving away from their parental populations or, in contrast, they could be carried back toward the island population by internal wave activity (Sangrà et al., 2001) when they regress shoreward on the eastern flank of the eddy. On the other hand, decapod larvae of pelagic species (mainly sergestidae and oplophoridae shrimps) were strongly associated with the eddy and excluded from coastal stations. This is probably related to the distribution of adults in pelagic oceanic waters, where they spawn. It has been proposed that eddies can enhance retention of crab larvae along the NW continental shelf of the USA (Wing et al., 1995a, b) and retention of eggs and fish larvae near islands (Lobel and Robinson, 1988; Boehlert et al., 1992; Rodríguez et al., 2001; Sponaugle et al., 2002). Cyclonic eddies in their early formation stages may increase primary production by pumping higher-nutrient water into the euphotic zone (Arístegui and Montero, 2005), thus favouring the enhancement of zooplankton. This suggests that eddies downstream of the Canary Islands are sites not only of retention, but also of increased growth and survival for larvae (Queiroga and Blanton, 2004), because of the greater amounts of food available compared with the surrounding oligotrophic oceanic areas (Barton et al., 1998).

The waters SE of Gran Canaria were characterised by the boundary between the oceanic waters and the upwelling filament arising from NW Africa coast near Cape Juby (Arístegui et al., 1997; Arístegui and
Montero, 2005). Most of the taxa studied were excluded from this structure; however, others, such as mollusca larvae, were clearly related to the filament. Accordingly, the Lagrangian simulations developed in Rodríguez et al. (2001) showed that particles originating near the islands did not cross the filament front, which functioned as a barrier impeding any extension of island larvae towards the S-SE, so the larvae collected at the filament stations clearly must come from African populations. Therefore, the presence of Parapenaeus longirostris larvae in the filament waters at Station 54 suggests the transport of this species towards Gran Canaria. However, permanent adult populations have not been reported around the Canary Islands, although this species is common over the African shelf (González-Pérez, 1995; Udekem D’Acoz, 1999). Previous studies have shown that these upwelling filaments can transport neritic fish larvae from the African coast to the Canary Islands (Rodríguez et al., 1999; Rodríguez et al., 2004; Bécognée et al., 2006).

In general, our results are in agreement with the findings of Rodríguez et al. (2001) on the spatial variability of ichthyoplankton around Gran Canaria during the same cruise. Thus, the meroplanktonic organisms are retained and/or dispersed because of the strong oceanographic variability around the islands. The different patterns of distribution among taxa could arise from the diversity of larval behaviour during the planktonic phase. Specifically, the capability of larvae to control their direction, frequency and speed of swimming to select different streams can influence their transport (Shanks, 1995).

In conclusion, our observations suggest that retention is possible near the islands to maintain the local populations and that the cyclonic eddy found off the island could help to enhance the local recruitment of the neritic larvae that escape offshore. Finer-scale studies focusing on the role of the physical features and of larval motility in the mechanisms of larval retention on the island shelf and in the introduction of larvae to the islands from the NW African continental shelf are necessary in order to understand the dynamics of the island populations.

\section{ACKNOWLEDGEMENTS}

We would like to thank the crew of the RV Ignat Pavlyuchenkov for their help with over-the-side operations. We thank the editor and anonymous review- 
ers for their helpful comments and suggestions. This work was funded by the MAST 0031 project of the European Union and the ConAfrica project (CICYT, CTM2004-02319) of the Ministerio de Educación y Ciencia. JML was supported by a postgraduate grant (BES-2005-10960) from the European Social Fund.

\section{REFERENCES}

Arístegui, J., P. Sangrá, S. Hernández-León, M. Cantón, A. Hernández-Guerra and J.L. Kerling. - 1994. Island-induced eddies in the Canary Islands. Deep-Sea Res. I, 41: 1509-1525

Arístegui, J., P. Tett, A. Hernández-Guerra, G. Basterretxea, M.F. Montero, K. Wild, P. Sangrá, S. Hernández-León, M. Cantón, J.A. García-Braun, M. Pacheco and E.D. Barton. - 1997. The influence of island generated eddies on chlorophyll distribution: a study of mesoscale variation around Gran Canaria. Deep-Sec Res. I, 44: 71-96.

Arístegui, J. and M.F. Montero. - 2005. Temporal and spatial changes in plankton respiration and biomass in the Canary Islands region: the effect of mesoscale variability. J. Mar. Syst., 54: 65-82.

Barton, E.D., J. Arístegui, P. Tett, N. Canto, J. García-Braun, S. Hernández-León, et al. - 1998. The transition zone of the Canary Current upwelling region. Progr. Oceanogr., 41: 455-504.

Barton, E.D., G. Basterretxea, P. Flament, E.G. Mitchelson-Jacob, B. Jones, J. Arístegui and F. Herrera. - 2000. Lee region of Gran Canaria. J. Geophys. Res., 105: 17173-17194.

Barton, E.D. P. Flament, H. Dodds and E. Mitchelson-Jacob. - 2001. Mesoscale structure viewed by SAR and AVHRR near the Canary Islands. Sci. Mar., 65(Suppl. 1): 165-175.

Barton, E.D., J. Arístegui, P. Tett and E. Navarro-Pérez. - 2004. Variability in the Canary Islands area of the filaments-eddy exchanges. Progr. Oceanogr., 62: 71-94.

Bécognée, P., C. Almeida, A. Barrera, A. Hernández-Guerra and S. Hernández-León. - 2006. Annual cycle of clupeiform larvae around Gran Canaria Island, Canary Islands. Fish. Oceanogr., 15: 293-300.

Boehlert, G., W. Watson and L. Sun. - 1992. Horizontal and vertical distributions of larval fishes around an isolated oceanic island in the tropical Pacific. Deep Sea Res., part A. 39: 439-466.

Cowen, R.K. - 2002. Larval dispersal and retention and consequences for population connectivity. In: P.F. Sale (ed.), Ecology of Coral Reef fishes: Recent Advances. Academic Press.

Dos Santos, A. and J.A. Lindley. - 2001. Crustacea Decapada: Larvae. II Dendrobranchiata. (Aristeidae, Benthesicymidae, Penaeidae, Solenoceridae, Sicyonidae, Sergestidae and Luciferidae). Fiches d'Identification du Zooplancton, 30: 1-15.

Dos Santos, A. and J.I. González-Gordillo. - 2004. Illustrated key for the identification of the Pleocyemata (Crustacea: Decapoda) zoeal stages, from the coastal region of south-western Europe. J. Mar. Biol. Ass. U.K., 84: 205-227.

González-Pérez, J.A. - 1995. Catálogo de Crustáceos Decápodos de Las Islas Canarias. Turquesa, Tenerife.

Hernández-Guerra, A.. J. Arístegui, M. Cantón and L. Nykjaer. - 1993. Phytoplankton pigment patterns in the Canary Islands as determined using Coastal Zone Colour Scanner data. Int. J. Remote Sens., 14: 1431-1437.

Hernández-León, S. - 1991. Accumulation of mesozooplankton in a wake area as a causative mechanism of the "island-mass effect". Mar. Biol., 109: 141-147.

Hernández-León, S., C. Almeida, M. Gómez, S. Torres, I. Montero and A. Portillo-Hahnefeld. - 2001. Zooplankton biomass and indices of feeding and metabolism in island-generated eddies around Gran Canaria. J. Mar. Syst., 30: 51-66.

Largier, J. - 2004. The importance of retention zones in the dispersal of larvae. Am. Fish. Soc. Symp., 45: 105-122.

Lobel, P.S. and A.R. Robinson. - 1988. Larval fishes and zooplancton in a cyclonic eddy in Hawaiian waters. J. Plankton Res., 10: $1209-1223$.

Pineda, J. - 1994. Internal tidal bores in the nearshore: warm-water front, seaward gravity current and the onshore transport of neustonic larvae. J. Mar. Res., 52: 427-458.

Queiroga H. and J. Blanton. - 2004. Interactions between behaviour and physical forcing in the control of horizontal transport of decapod crustacean larvae. Adv. Mar. Biol., 47: 107-214.

Rodríguez, J.M. S. Hernández-León and E.D. Barton - 1999. Mesoscale distribution of fish larvae in relation to an upwelling filament off northwest Africa. Deep-Sea Res. I, 46: 1969-1984.

Rodríguez, J.M., E.D. Barton, L. Eve and S. Hernández-León. - 2001. Mesozooplankton and ichthyoplankton distribution around Gran Canaria, an oceanic island in the NE Atlantic. Deep-Sea Res. I, 48: 2161-2183.

Rodríguez, J.M., E.D. Barton, S. Hernández-León and J. Arístegui. - 2004. The influence of mesoscale physical processes on the larval fish community in the Canaries CTZ, in summer. Progr. Oceanogr., 62: 171-188.

Sangrà, P., G. Basterretxea, J.L. Pelegrí and J. Arístegui. - 2001. Chlorophyll increase due to internal waves on the shelf break of Gran Canaria (Canary Islands). Sci. Mar., 65(Suppl. 1): 89-97.

Sangrà, P., M. Auladell, A. Marrero-Díaz, J.L. Pelegrí, E. FraileNuez, A. Rodríguez-Santana, J.M. Martín, E. Mason and A. Hernández-Guerra. - 2007. On the nature of oceanic eddies shed by the Island of Gran Canaria. Deep-Sea Res. I, 54, 687-709.

Shanks, A.L. - 1995. Mechanisms of cross-shelf dispersal of larval invertebrates and fish. In: D. McEdward (ed.), Ecology of Marine Invertebrates. CRC Press.

Shanks, A.L., A. McCulloch and J. Miller. - 2003. Topographically generated fronts, very nearshore oceanography and the distribution of larval invertebrates and holoplankters. J. Plankton Res., 25(10): 1251-1277.

Shanks, A.L. and G.L. Eckert. - 2005. Population persistence of California current fishes and benthic crustaceans: a marine drift paradox. Ecol. Monogr., 75 (4): 505-524.

Sponaugle, S., R. Cowen, A. Shanks, S. Morgan, J. Leis, J. Pineda, G. Boehlert, M. Kingsford, K. Lindeman, Ch. Grimes and J. Munro. - 2002. Predicting shelf-recruitment in marine populations: Biophysical correlates and mechanisms. Bull. Mar. Sci., 70: $341-375$

Udekem D'Acoz, C. - 1999. Inventaire et distribution des crustacés décapodes de l'Atalantique nord-oriental, de la Méditerraée et des eaux continentales adjacentes au nord de $25^{\circ} \mathrm{N}$. Patrimoines naturels 40. MNHN/SPN, Paris.

Vélez-Muñoz, H.S. - 1992. Ignat Pavlyuchenkov cruise report: Hydrographic fields. Data Report 0031-09, School of Ocean Sciences, University of Wales, Bangor, UK

Wing, S.R., L.V. Botsford, J.L. Largier and L.E. Morgan. - 1995a. Spatial structure of relaxation events and crab settlement in the northern California upwelling system. Mar. Ecol. Prog. Ser., 128: 199-211.

Wing, S.R., J.L. Largier, L.V. Botsford and J.F. Quinn. - 1995b. Settlement and transport of benthic invertebrates in an intermittent upwelling region. Limnol. Oceanogr., 40: 316-329.

Zariquiey Álvarez, R. - 1968. Crustáceos decápodos ibéricos. Invest. Pesq., 32: 1-510.

Scient. ed.: M.P. Olivar.

Received July 1, 2008. Accepted April 21, 2009.

Published online August 6, 2009. 